\title{
Development of Indirect Spectrophotometric Method for Quantification of Cephalexin in Pure Form and Commercial Formulation Using Complexation Reaction
}

\author{
Muhammad Naeem Khan*, Sundus Kalsoom, Rahana Hussain, \\ Zarbad Shah and Muhammad Saadiq \\ Department of Chemistry, Bacha Khan University, Charsadda, KPK, Pakistan. \\ *Corresponding Author Email: mnaeemchemist@yahoo.com \\ Received 21 May 2016, Revised 23 September 2016, Accepted 25 September 2016
}

\begin{abstract}
A simple, accurate and indirect spectrophotometric method was developed for the quantification of cephalexin in pure form and pharmaceutical products using complexation reaction. The developed method is based on the oxidation of the cephalexin with $\mathrm{Fe}^{3+}$ in acidic medium. Then 1, 10phenanthroline reacts with $\mathrm{Fe}^{2+}$ and a red colored complex was formed. The absorbance of the complex was measured at $510 \mathrm{~nm}$ by spectrophotometer. Different experimental parameters affecting the complexation reactions were studied and optimized. Beer's law was obeyed in the concentration range $0.4-10 \mu \mathrm{gmL}^{-1}$ with a good correlation of 0.992 . The limit of detection and limit of quantification were found to be $0.065 \mu \mathrm{gmL}^{-1}$ and $0.218 \mu \mathrm{gmL}^{-1}$, respectively. The method have good reproducibility with a relative standard deviation of $6.26 \%(n=6)$. The method was successfully applied for the determination of cephalexin in bulk powder and commercial formulation. Percent recoveries were found to range from 95.47 to $103.87 \%$ for the pure form and 98.62 to $103.35 \%$ for commercial formulations.
\end{abstract}

Keywords: Cephalexin, Spectrophotometry, Pharmaceutical formulations, 1, 10-Phenonthroline.

\section{Introduction}

Cephalexin (7-[(aminophenyl acetyl) amino]-3methyl-8-oxo-5-thia-1-azabicyclo [4.2.0] oct-2-ene2 -carboxylic acid) is a semisynthetic $\beta$-lactam antibiotic, which belongs to the group of cephalosporin antibiotics. Cephalexin is a firstgeneration cephalosporin antibacterial used for the handling of vulnerable infections including those of respiratory tract, urinary tract and skin [1]. Cephalexin is an active broad spectrum antibiotic that targets both Gram positive and Gram negative bacteria [2]. Cephalexin is an effective cephalosporin and shows a broad spectrum of antibiotic activity, weak bond capability to blood protein, no metabolites, and low toxicity and to be quickly absorbed following oral administration to give a high serum levels and urine concentration. Therefore, the cephalexin is widely used for clinical chemotherapy [3,4]. The extensive use of cephalexin make a clinical and pharmacological study needs a simple, fast and sensitive analytical method to determine the drug in commercial formulations and biological samples.

A number of methods have been described in the literature for the determination of cephalexin. These include chromatographic methods [5-9], fluorometry [10-12], flow injection analysis [13,14], atomic absorption [15] and electroanalytical methods [16]. Limited spectrophotometric techniques are presented for the determination of cephalexin [17-20]. The first spectrophotometric method is based on the reaction of cephalexin with sodium 1, 2-naphthoquinone-4- 
sulfonate (NQS) and measured the absorbance at $475 \mathrm{~nm}$. The second spectrophotometric method is based on the reaction of cephalexin with ninhydrin reagent giving blue colored chromogen, which was measured at $576 \mathrm{~nm}$. These spectrophotometric methods involve prolonged procedures or have a narrow range of calibration curves. The aim of the present attempt was to develop a simple, accurate, selective and reproducible method for the determination of cephalexin in pure form and pharmaceutical preparations. The developed method is more sensitive than the published methods and is free from such experimental variables such as heating or extraction step.

\section{Materials and Methods Instruments}

A UV-Visible spectrophotometer SP-1800 (721 G) equipped with 1-cm matched glass cell was used for absorbance measurement. A digital analytical balance and a digital water bath, labacon, model LWB-104 was also used.

\section{Materials and reagents}

Analytical or high grade purity reagents were used. $\mathrm{FeCl}_{3} .6 \mathrm{H}_{2} \mathrm{O}$ and $\mathrm{H}_{2} \mathrm{SO}_{4}, 95-97 \%$ extra pure (Riedel-deHaën, Germany) and 1,10phenanthroline (S.A, Barcelona Spain) were used. Standard reference cephalexin was gifted by Saydon Pharmaceutical Industry (Pvt.) Ltd., Peshawar, Pakistan. Commercial formulation of cephalexin (Ceporex capsules $250 \mathrm{mg}$, manufactured by GlaxoSmithKline) Pakistan was purchased locally. $0.003 \mathrm{molL}^{-1} \mathrm{Fe}^{3+}$ fresh solution was prepared by dissolving $0.04 \mathrm{~g}$ iron chloride hexahydrate in volumetric flask and diluted to $50 \mathrm{~mL}$ with distilled water. $0.02 \mathrm{molL}^{-1}$ 1,10-phenanthroline solution was prepared by dissolving $0.198 \mathrm{~g}$ of reagent in $5.0 \mathrm{~mL}$ of methanol and diluting up to $50 \mathrm{~mL}$ with distilled water.

\section{Standard solution}

Standard stock solution of cephalexin (100 $\mu \mathrm{gmL}^{-1}$ ) was prepared by dissolving $0.005 \mathrm{~g}$ of standard cephalexin in distilled water by heating it for few minutes at $75{ }^{\circ} \mathrm{C}$ and after cooling diluted to $50 \mathrm{~mL}$ with distilled water. Working standard solutions of the required concentration were freshly prepared by dilution.

\section{Sample Solution}

The contents of five capsules of Ceporex containing $250 \mathrm{mg}$ of cephalexin were weighed and mixed. The average mass of the powder in one capsule was calculated. Proper amount of the drug powder equivalent to $0.01 \mathrm{~g}$ of cephalexin was dissolved in distilled water by heating it for few minutes at $75{ }^{\circ} \mathrm{C}$, filtered, transferred to a $100 \mathrm{~mL}$ volumetric flask and made the volume to the mark with distilled water. A working sample solution of $5 \mu \mathrm{gmL}^{-1}$ was prepared from stock sample solution by dilution with distilled water.

\section{General procedure}

Proper volumes of cephalexin standard stock solution to produce a final concentration of 0.4-10 $\mu \mathrm{gmL}^{-1}$ were taken in Erlenmeyer flasks. Then $1.0 \mathrm{~mL}$ of $\mathrm{Fe}^{3+}\left(0.003 \mathrm{molL}^{-1}\right)$ solution and $1.0 \mathrm{~mL}$ of 1,10 -phenanthroline $\left(0.02 \mathrm{molL}^{-1}\right)$ was added. The mixture was heated at $100{ }^{\circ} \mathrm{C}$ for 20 minutes on water bath and after cooling transferred to volumetric flasks and made the volume up to 10 $\mathrm{mL}$ with distilled water. The absorbance was measured at $510 \mathrm{~nm}$ on a spectrophotometer against a reagent blank.

\section{Results and Discussion}

When varying amount of cephalexin drug are reacted with a known and fixed amount of $\mathrm{Fe}^{3+}$ in acidic medium, proportionate amount of $\mathrm{Fe}^{3+}$ will be used for the oxidation of the drug, and there will a concurrent fall in $\mathrm{Fe}^{3+}$ concentration and a concomitant increase in the concentration of $\mathrm{Fe}^{2+}$. The amount of $\mathrm{Fe}^{2+}$ can be determined by using 1 , 10-phenanthroline. This property has been used for the determination of cephalexin in pharmaceutical preparations. The absorption spectra of the colored species show maximum absorbance at $510 \mathrm{~nm}$ (Fig. 1). The absorbance is 
linearly dependent on the concentration of cephalexin drug studied, forming the basis for the determination.

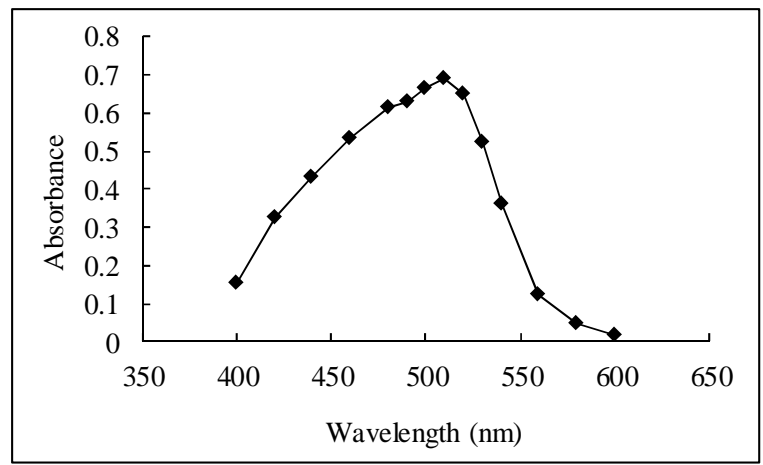

Figure 1. Absorption spectra for the colored product Conditions; $10 \mathrm{\mu gmL}^{-1}$ cephalexin, $1.0 \mathrm{~mL}$ of $\mathrm{Fe}^{3+}\left(0.003 \mathrm{molL}^{-1}\right)$, $1.0 \mathrm{~mL}$ of 1,10 phenanthroline $\left(0.02 \mathrm{molL}^{-1}\right)$, heated at $100{ }^{\circ} \mathrm{C}$ for $20 \mathrm{~min}$, diluted to $25 \mathrm{~mL}$

\section{Optimization of reaction parameters}

Different experimental parameters affecting the complexation reaction were carefully studied.

\section{Effect of heating temperature and time}

The effect of temperature in the range of $60-100{ }^{\circ} \mathrm{C}$ and heating time from 5 to 25 minutes was studied. Maximum color product was formed when the reaction mixture was heated for 20 minutes at $100{ }^{\circ} \mathrm{C}$ (Fig. 2, 3).

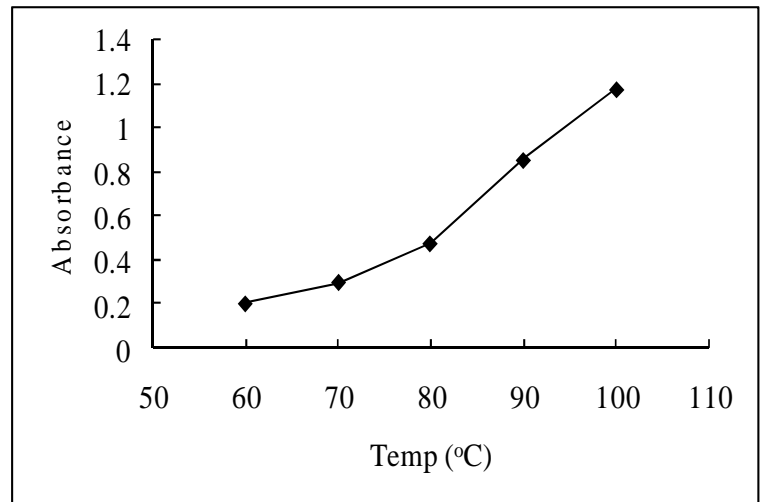

Figure 2. Effect of temperature on absorbance

Conditions; $10 \mu \mathrm{gmL}^{-1}$ cephalexin, $1.0 \mathrm{~mL}$ of $\mathrm{Fe}^{3+}\left(0.003 \mathrm{molL}^{-1}\right)$, $1.0 \mathrm{~mL}$ of 1,10 phenanthroline $\left(0.02 \mathrm{molL}^{-1}\right)$, heated at $60-100{ }^{\circ} \mathrm{C}$ for $20 \mathrm{~min}$, diluted to $25 \mathrm{~mL}$

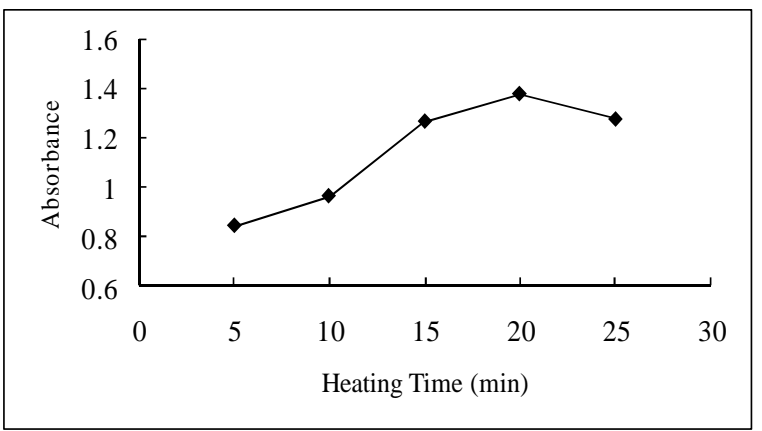

Figure 3. Effect of heating time on absorbance Conditions: $10 \mu \mathrm{gmL}^{-1}$ cephalexin, $1.0 \mathrm{~mL}$ of $\mathrm{Fe}^{3+}\left(0.003 \mathrm{molL}^{-1}\right)$, $1.0 \mathrm{~mL}$ of 1,10 phenanthroline $\left(0.02 \mathrm{molL}^{-1}\right)$, heated at $100{ }^{\circ} \mathrm{C}$ for 5-25 min, diluted to $25 \mathrm{~mL}$

Effect of concentration and volume of $\mathrm{Fe}^{3+}$ solution

The effect of concentration of $\mathrm{Fe}^{3+}$ was also studied in the range of 0.001 to $0.005 \mathrm{molL}^{-1}$. It was observed that maximum color formation was occurred with $0.003 \mathrm{molL}^{-1} \mathrm{Fe}^{3+}$ (Fig. 4). The effect of volume of $0.003 \mathrm{molL}^{-1} \mathrm{Fe}^{3+}$ was also studied and it was found that $1.0 \mathrm{~mL}$ was found to produce maximum absorbance.

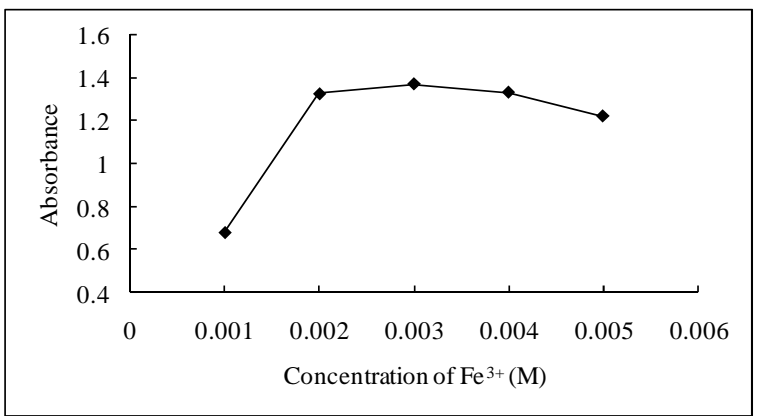

Figure 4. Effect of $\mathrm{Fe}^{3+}$ concentration on absorbance

Conditions; $10 \mu \mathrm{gmL}^{-1}$ cephalexin, $1.0 \mathrm{~mL}$ of $\mathrm{Fe}^{3+}(0.001-0.005 \mathrm{~mol}$ $\left.\mathrm{L}^{-1}\right), 1.0 \mathrm{~mL}$ of 1,10 Phenanthroline $\left(0.02 \mathrm{molL}^{-1}\right)$, heated at 100 ${ }^{\circ} \mathrm{C}$ for $20 \mathrm{~min}$, diluted to $25 \mathrm{~mL}$

Effect of concentration and volume of 1, 10phenanthrolin solution

The effect of concentration of 1,10phenanthroline was investigated in the range of 0.006 to $0.05 \mathrm{molL}^{-1}$. Maximum absorbance was observed with 0.02 molL $^{-1}$ (Fig. 5). The effect of volume of 1,10-phenanthroline solution was also investigated and it was found that maximum colored formation was produced with $1.0 \mathrm{~mL}$ of 1,10-phenanthrolin. 


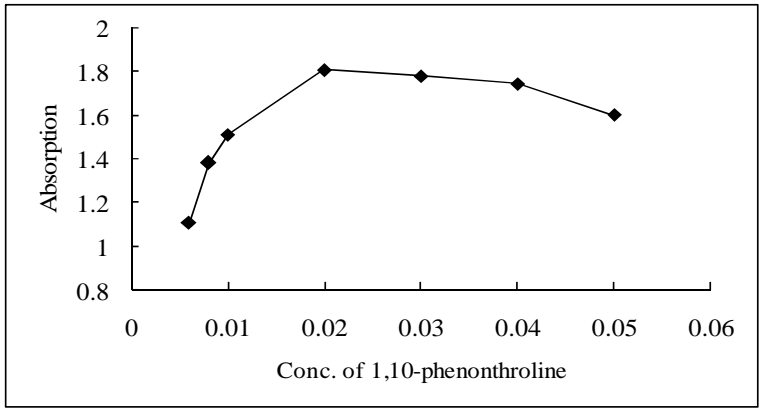

Figure 5. Effect of concentration of 1, 10-phenonthroline Conditions; $10 \mu \mathrm{gmL}^{-1}$ cephalexin, $1.0 \mathrm{~mL}$ of $\mathrm{Fe}^{3+}\left(0.003 \mathrm{molL}^{-1}\right)$, $1.0 \mathrm{~mL}$ of 1,10 phenanthroline $\left(0.006-0.05 \mathrm{molL}^{-1}\right)$, heated at 100 ${ }^{\circ} \mathrm{C}$ for $20 \mathrm{~min}$, diluted to $25 \mathrm{~mL}$

\section{Stability}

The stability of the reaction product was studied by measuring the absorbance after 10 minutes intervals up to 120 minutes. It was investigated that no change in absorbance of the reaction product was observed. Thus, the reaction product is stable and will not affect the result of analysis even if the absorbance of the reaction product is measured after 2 hours of dilution (Fig. 6).

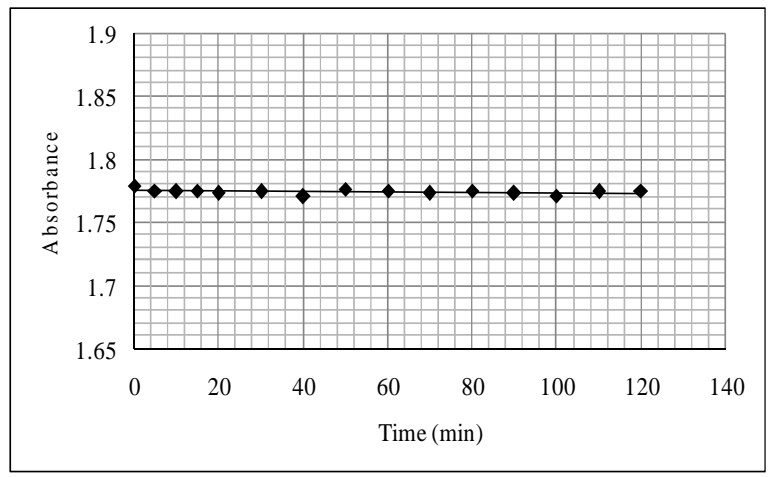

Figure 6. Effect of time on stability of reaction product after dilution

Conditions; $10 \mu \mathrm{gmL}^{-1}$ cephalexin, $1.0 \mathrm{~mL}$ of $\mathrm{Fe}^{3+}\left(0.003 \mathrm{molL}^{-1}\right)$, $1.0 \mathrm{~mL}$ of 1,10 phenanthroline $\left(0.02 \mathrm{molL}^{-1}\right)$, heated at $100{ }^{\circ} \mathrm{C}$ for $20 \mathrm{~min}$, diluted to $25 \mathrm{~mL}$

\section{Effect of interferences}

The interferences effect from commonly used excipients in pharmaceutical preparations of cephalexin was investigated (Fig.7). These excipients include sucrose, starch and glucose. Under the same experimental conditions, these excipients were added to a known amount of drug (cephalexin $0.4 \mu \mathrm{gmL}^{-1}$ ), in different concentration in the ratio of 1:1, 1:2, 1:4, 1:6, 1:8 and 1:10. The mixtures containing drug and excipients were analyzed by the proposed method. None of these common excipients was found to cause interference.

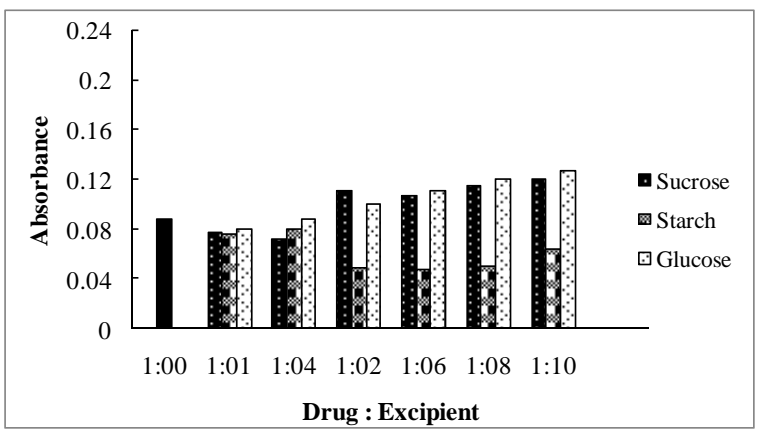

Figure 7. Effect of common excipients on determination of cephalexin by the proposed method

\section{Analytical figures of merit}

Under the optimized conditions of the proposed method, Beer's law was obeyed in the concentration range $0.4-10 \mu \mathrm{g} \mathrm{mL}^{-1}$ with a good correlation of 0.992 (Fig. 8). The LOD and LOQ values were calculated and found to be 0.0654 $\mu \mathrm{gmL}^{-1}$ and $0.218 \mu \mathrm{gmL}^{-1}$, respectively. The analytical parameters are given in Table 1 . The sensitivity of the method is compared with other reported methods (Table 2), which show that sensitivity of the present method is superior to those of previously reported methods.

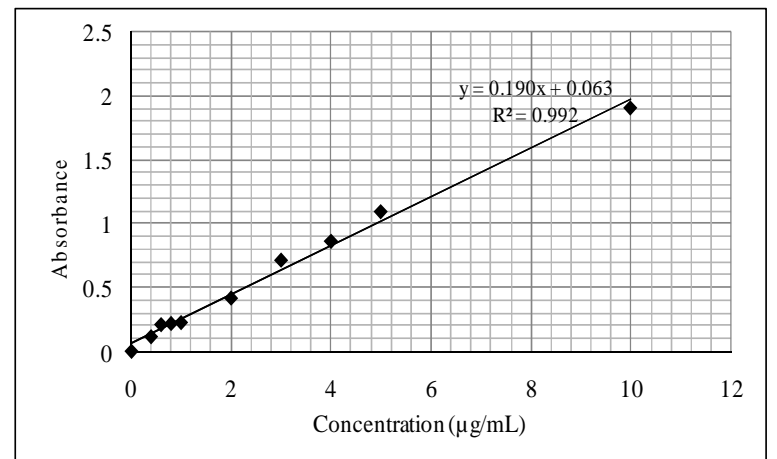

Figure 8. Effect of concentration of cephalexin on absorbance Conditions; 0.4 - $10 \mu \mathrm{gmL}^{-1}$ cephalexin, $1.0 \mathrm{~mL}$ of $\mathrm{Fe}^{3+}(0.003$ molL $\left.{ }^{-1}\right), 1.0 \mathrm{~mL}$ of 1,10 Phenanthroline $\left(0.02 \mathrm{molL}^{-1}\right)$, heated at $100{ }^{\circ} \mathrm{C}$ for $20 \mathrm{~min}$, diluted to $25 \mathrm{~mL}$ 
Table 1. Analytical parameters for the spectrophotometric determination of cephalexin.

\begin{tabular}{lc}
\hline \multicolumn{1}{c}{ Parameters } & Value \\
\hline$\lambda_{\max }(\mathrm{nm})$ & 510 \\
Linear range $\left(\mu \mathrm{gmL}^{-1}\right)$ & $0.4-10$ \\
Limit of detection $\left(\mu \mathrm{gmL}^{-1}\right)$ & 0.0654 \\
Limit of quantification $\left(\mu \mathrm{gmL}^{-1}\right)$ & 0.218 \\
Regression equation $(\mathrm{y})$ & $\mathrm{Y}=0.190 \mathrm{X}+0.063$ \\
Slope $(\mathrm{b})$ & 0.190 \\
Intercept $(\mathrm{a})$ & 0.063 \\
Correlation coefficient $\left(\mathrm{r}^{2}\right)$ & 0.992 \\
Standard deviation $\left(\mu \mathrm{gmL} \mathrm{L}^{-1}\right)$ & 0.0218 \\
Relative standard deviation $(\%)$ & 6.26 \\
\hline
\end{tabular}

Table 2. Comparison of the present method and other reported methods for the determination of cephalexin levels.

\begin{tabular}{lccc}
\hline Methods & $\begin{array}{c}\text { Linear } \\
\text { range }\end{array}$ & $\begin{array}{c}\text { Limit of } \\
\text { Detection (LOD) }\end{array}$ & References \\
\hline Spectrofluorimety & $0.04-0.4$ & 7.76 & {$[12]$} \\
& $\mu g \mathrm{gm}^{-1}$ & $\mathrm{ngmL}$ & \\
Atomic absorption & $5-50$ & 1.66 & {$[15]$} \\
spectroscopy & $\mu \mathrm{gmL} L^{-1}$ & $\mu \mathrm{gmL}^{-1}$ & \\
Spectrophotometry & $5-60$ & 1.22 & {$[18]$} \\
& $\mu \mathrm{gmL}^{-1}$ & $\mu \mathrm{gmL}^{-1}$ & \\
Spectrophotometry & $1.5-10$ & 0.90 & {$[19]$} \\
& $\mu g \mathrm{gL}^{-1}$ & $\mu \mathrm{gmL}^{-1}$ & \\
HPLC & $10-110$, & 2.236, & {$[21]$} \\
& $10-120$ & 2.090 & \\
Spectrophotometry & $\mu \mathrm{gmL}^{-1}$ & $\mu \mathrm{gmL}^{-1}$ & \\
& $0.4-10$ & 0.065 & Present \\
& $\mu \mathrm{gmL}^{-1}$ & $\mu \mathrm{gmL}^{-1}$ & method \\
\hline
\end{tabular}

\section{Reliability of the method}

The precision of the method was checked by evaluating cephalexin in pure form and pharmaceutical preparations at three different concentrations in triplicate within the Beer's law range. The results are summarized in Table 3 for pure form and Table 4 for dosage form. The percentage recoveries obtained ranged from 95.47 to $103.87 \%$ for the pure form and 98.62 to $103.35 \%$ for dosage form. The RSD value was found to be satisfactory (RSD $\leq 6.5)$ showing good reproducibility of the method. Accuracy of the method was calculated by the standard addition method using one brand of capsule (ceporex containing $250 \mathrm{mg}$ of cephalexin). Specific concentrations of standard cephalexin solution were added to commercial formulation and investigated by the described procedure. Percent recoveries were calculated and ranged from 99.01$102.13 \%$ (Table 5).
Table 3. Evaluation of accuracy and precision of the proposed method using solutions of pure cephalexin.

\begin{tabular}{|c|c|c|c|}
\hline $\begin{array}{c}\text { Amount } \\
\text { taken } \\
\left(\mu \mathrm{gmL}^{-1}\right)\end{array}$ & $\begin{array}{c}\text { Amount } \\
\text { found } \\
\left(\mu \mathrm{gmL}^{-1}\right)\end{array}$ & $\begin{array}{c}\% \text { Recovery } \pm \\
\text { RSD }\end{array}$ & $\begin{array}{c}\text { Confidence } \\
\text { limit }\end{array}$ \\
\hline 0.4 & 0.402 & $100.5 \pm 9.98$ & $100.50 \pm 0.24 \%$ \\
\hline 0.6 & 0.5728 & $95.47 \pm 12.21$ & $95.47 \pm 0.30 \%$ \\
\hline 0.8 & 0.8310 & $103.87 \pm 2.16$ & $103.87 \pm 0.05 \%$ \\
\hline Mean $=$ & & \multicolumn{2}{|c|}{92.31} \\
\hline$\pm \mathrm{SD}=$ & & \multicolumn{2}{|c|}{13.41} \\
\hline t-test $=$ & & \multicolumn{2}{|c|}{$0.9920(4.303)$} \\
\hline
\end{tabular}

Table 4. Evaluation of accuracy and precision of the proposed method for cephalexin determination in pharmaceutical preparation.

\begin{tabular}{cccc}
\hline $\begin{array}{c}\text { Pharmaceutical } \\
\text { preparations }\end{array}$ & $\begin{array}{c}\text { Amount } \\
\text { taken } \\
\left(\boldsymbol{\mu \text { gmL } ^ { - 1 } )}\right.\end{array}$ & $\begin{array}{c}\text { Amount } \\
\text { found } \\
\left(\boldsymbol{\mu \text { gmL } ^ { - 1 } )}\right.\end{array}$ & $\begin{array}{c}\text { \% Recovery } \\
\mathbf{1} \text { RSD }\end{array}$ \\
\hline $\begin{array}{c}\text { Ceporex } \\
\text { capsules }\end{array}$ & 0.4 & 0.401 & $100.00 \pm 9.98$ \\
250 mg & 0.6 & 0.591 & $98.62 \pm 3.93$ \\
\hline
\end{tabular}

Results are the averages of three separate analyses; RSD = Relative standard deviation

Table 5. Evaluation of recovery test of cephalexin in commercial formulation (capsules) by the proposed method.

\begin{tabular}{ccccc}
\hline Sample & $\begin{array}{c}\text { Sample } \\
\left(\boldsymbol{\mu g m L} \mathbf{- 1}^{-1}\right)\end{array}$ & $\begin{array}{c}\left(\boldsymbol{\mu g m L} \mathbf{~}^{-1}\right) \\
\text { added }\end{array}$ & $\begin{array}{c}(\boldsymbol{\mu g m L} \\
\text { found }\end{array}$ & $\begin{array}{c}\text { \% Recovery } \pm \\
\text { RSD }\end{array}$ \\
\hline Ceporex & & 0.4 & 0.81 & $102.13 \pm 7.75$ \\
capsules & 0.4 & 0.6 & 1.01 & $101.0 \pm 3.59$ \\
$250 \mathrm{mg}$ & & 0.8 & 1.22 & $99.01 \pm 5.72$ \\
\hline
\end{tabular}

Results are the averages of three separate analyses; RSD $=$ Relative standard deviation

\section{Application}

The proposed method has been effectively applied for the determination of cephalexin in commercial formulation. The result of the proposed method obtained showed close agreement with the label claims without any interference. The results were statistically compared using student's t-test for accuracy (Table 6).

Table 6. Determination of cephalexin in commercial formulations.

\begin{tabular}{lccc}
\hline Brand name & \multicolumn{2}{c}{ Active ingredient $\left(\right.$ mgcap $\left.^{-1}\right)$} & t-test value \\
\cline { 2 - 3 } & Labeled value & Found value & $\mathbf{( 4 . 3 0 3 )}$ \\
Ceporex & 250 & 250.43 & -7.45 \\
capsules $250 \mathrm{mg}$ & & & \\
\hline Results are the averages of three separate analyses; RSD $=$ Relative
\end{tabular}
standard deviation 


\section{Conclusion}

A sensitive, simple and selective spectrophotometric method was developed for determination of cephalexin in pure form and commercial formulation. Compared with HPLC and LC/MS methods, the proposed method is simple and does not need any pretreatment or lengthy procedure. The developed method was found to have a wider linear range and can be used as an alternative to HPLC for the determination of cephalexin in industrial and research institution laboratories.

\section{Acknowledgments}

The authors extend their appreciation to the Bacha Khan University, Charsadda, KPK, Pakistan for providing the facility to conduct this research.

\section{References}

1. S. C. Sweetman, Eds. In The Martindale: The Complete Drug Reference. $35^{\text {th }}$ ed. London, UK, Pharmaceutical Press, (2007) 194.

2. L. S. Goodman, A. Gilman and Antimicrobial agents, in: J. G. Hardnab, L. L. Limbird, and A. G. Gilman, (Eds.), The Pharmacological Basis of Therapeutics, $10^{\text {th }}$ ed., McGraw-Hill, New York (2001).

3. T. Nakagawa, J. Haginaka, K. Yamaoka and T. Uno, J. Antibiotic, 31 (1978) 769. http://doi.org/10.7164/antibiotics.31.769

4. P. Campíns-Falcó, A. Sevillano-Cabeza, L. Gallo-Martínez, F. Bosch-Reig and I. Monzó- Mansanet, Mikrochim. Acta., 126 (1997) 207. https://doi.org/10.1007/BF01242322

5. M. A. Carroll, E. R. White, Z. Jancsik and J. E. Zarembo, J. Antibiotic, 30 (1977) 397. http://doi.org/10.7164/antibiotics.30.397

6. M. C. Hsu, Y. S. Lin and H. C. Chung, J. Chromatog. A, 692 (1995) 67. http://doi:10.1016/0021-9673(94)00688-6

7. M. C. Hsu, H. C. Chung and Y. S. Lin, J. Chromatog. A, 727 (1996) 239. http://dx.doi.org/10.1016/00219673(95)01119-6
8. S. A. Coran, M. Bambagiotti-Alberti, V. Giannellini, A. Baldi, G. Picchioni and F. Paoli, J. Pharm. Biom. Anal., 18 (1998) 271. https://doi.org/10.1016/S07317085(98)00167-8

9. R. M. Jeswani, P. K. Sinha, K. S. Topagi and M. C. Damle, Int. J. Pharm. Tech. Res., 1 (2009) 527. http://citeseerx.ist.psu.edu/ doi=10.1.1.513.6062\&rep=rep1\&type=pdf

10. J. L. Fabregas and J. E. Beneyto, Analyst, 105 (1980) 813. https://doi.org/10.1039/an9800500813

11. F. Plavšić, B. Vrhovac, A. Radošević and I. Dvorźak, J. Clin. Chem. Clin. Biochem., 19 (1981) 35 . https://doi.org/10.1515/cclm.1981.19.1.35,

12. R. Dalia El Wasseef, Spectrosc. Lett., 40 (2007) 797. https://doi.org/10.1080/00387010701506588

13. U. J. Meyer, Z. L. Zhi, E. Loomans, F. Spener and M. Meusel, Analyst, 124 (1999) 1605. https://doi.org/10.1039/a907121k

14. Z. L. Zhi, U. J. Meyer, J. W. Van den Bedem and M. Meusel, Anal. Chim. Acta, 442 (2001) 207. https://doi.org/10.1016/S00032670(01)01180-1

15. S. M. AL-Ghannam, J. Food Drug Anal., 16 (2008) 19

http://search.proquest.com/openview/686fa6 8d7f1a1117006c7156d658fdb0/1

16. M. Xu, H. Ma and J. Song, J. Pharm. Biom. Anal., 35 (2004) 1075. https://doi.org/10.1016/j.jpba.2004.03.018

17. M. Irandoust, M. Shariati-Rad and K. Mina, IJPSR, 5 (2014) 97. http://dx.doi.org/10.13040/IJPSR.0975-8232

18. S. A. Patel and N. J. Patel, Int. Res. J. Pharm., 2 (2011) 145. $\mathrm{http} / / /$ journals.indexcopernicus.com/abstract. php?icid $=982222$

19. O. H. Rebwar, Chem. Sci. Trans., 2 (2013) 1110. doi.10.7598/cst2013.449

$20 . \quad$ A. H. Rageh, S.R. El-Shaboury, G. A. Saleh, F. A. Mohamed, Nat. Sci., 2 (2010) 828. doi: $10.4236 / n s .2010 .28104$

21. A. J. Abdulghani, H. H. Jasim and A. S. Hassan, Pak. J. Chem., 2 (2012) 1. https://doi.org/10.15228/2012.v02.i03.p08 